\title{
Corporate Farming for Farmer Labor Efficiency in Trimulyo Village, Bantul Regency
}

\author{
Neti Herlina ${ }^{a, 1}$, Ismiasih ${ }^{b, 2}{ }^{*}$, Tri Endar Suswatiningsih c,3 \\ a,b,c Department of Agribusiness, Faculty of Agriculture, INSTIPER, Jalan Nangka II, Maguwoharjo Yogayakarta. 55282. Indonesia \\ ${ }^{1}$ netiherlina02@gmail.com; ${ }^{2}$ ismiasih@instiperjogja.ac.id ; ${ }^{3}$ endar_instiper@yahoo.co.id \\ * corresponding author
}

\begin{tabular}{|c|c|}
\hline ARTICLE INFO & ABSTRACT \\
\hline $\begin{array}{l}\text { Article history. } \\
\text { Received March 15, } 2021 \\
\text { Revised June 22, } 2021 \\
\text { Accepted October 05, } 2021 \\
\text { Published October 29, } 2021 \\
\text { Keywords } \\
\text { Corporate farming } \\
\text { Impact } \\
\text { Efficiency } \\
\text { Labor }\end{array}$ & $\begin{array}{l}\text { Agriculture is one of the dominant sectors in the economic structure in Daerah Istimewa } \\
\text { Yogyakarta. This is because the agricultural sector contributes to meeting food needs } \\
\text { and the supply of industrial raw materials. The corporate farming (CF) program located } \\
\text { in desa Trimulyo, Daerah Istimewa Yogyakarta is one of the empowerment programs } \\
\text { for farming communities by farming in groups. The purpose of this study was to } \\
\text { determine the implementation of the CF program and the impact of the CF program on } \\
\text { labor efficiency at the farm level. The research method used was descriptive qualitative } \\
\text { and quantitative with t-test. The method of determining the sample was purposive with } \\
30 \text { farmers as respondents. The technique of collecting data was done by observation, } \\
\text { interview and questionnaire. The results showed that the CF program is a program by } \\
\text { combining several farmer-owned lands into one large area (land consolidation) and } \\
\text { carried out jointly in one management from land preparation to harvest using modern } \\
\text { agricultural tools and machines. The rice productivity produced by farmers before the } \\
\text { CF program was } 323.03 \mathrm{Kg} / \mathrm{UT} \text { or } 3,654.05 \mathrm{Kg} / \mathrm{Ha} \text {. After the existence of the } \\
\text { productivity program is } 268.13 \mathrm{Kg} / \mathrm{UT} \text { or } 3,032 \mathrm{Kg} / \mathrm{Ha} \text {. The need for labour in one } \\
\text { season prior to the program was } 43.8 \mathrm{HOK} / \mathrm{UT} \text { or } 1,464.76 \mathrm{HOK} / \mathrm{Ha} \text {. The need for labor } \\
\text { after the program was } 31.52 \mathrm{HOK} / \mathrm{UT} \text { or } 716.79 \mathrm{HOK} / \mathrm{Ha} \text {. The impact of the CF } \\
\text { program on labor efficiency shows no significant difference. This means that the } \\
\text { efficiency of the labor before and after the program is the same. } \\
\text { This is an open access article under the CC-BY-SA license }\end{array}$ \\
\hline
\end{tabular}

\section{INTRODUCTION}

Most people in Indonesia work as farmers. Based on BPS (2021) there are about 33.4 million farmers engaged in the agricultural sector. However, the majority of the farmers are just doing what they can do. This means that farmers are cultivating their agricultural land without thinking about profits, especially for food 
farmers such as rice. They work on their agricultural land only to meet their daily needs, or as subsistence farmers. According to the Ministry of Agriculture (2021), farmers are the main actors in agricultural development, meaning that it is farmers who play an important role as development actors. Hence, to improve the welfare of farmers, farmers must try to increase their productivity by working more effectively and efficiently.

Agriculture as a sub-sector is quite important in supporting the economic structure in the Special Region of Yogyakarta (DIY). This is because the agricultural sector plays a role in meeting food needs, providing industrial raw materials, absorbing large numbers of workers, and contributing highly to regional income. This shows that the development of the agricultural sector is one of the pillars of most people in DIY, especially in rural areas. The dominance of the agricultural sector also shows that the agricultural sector needs to be handled in a sustainable manner because it is related to achieving farmers' welfare.

In the current era of globalization, there is a lot of competition. Especially with the implementation of free market competition, every farmer would want high production yields with efficient work. Efficient work results will certainly produce higher profits for rice farmers. Therefore, an empowerment program is very crucial for farmers so that the production and productivity achieved can be further increased. Given that the average farmer in Indonesia in managing their farming is still subsistence, which is cultivating agricultural land conventionally with the aim of meeting daily needs, not for the purpose of making a profit.

Farming in general has the following characteristics: not a legal entity, narrow land (less than $0.5 \mathrm{ha}$ ), lack of capital, manual use of agricultural technology, and a large amount of labor (Suratiyah, 2015). It is an obstacle for farmers to increase their farming because, as it has been widely known that, the production of a farm certainly requires capital such as for the purchase of: fertilizers, pesticides, agricultural tools and the provision of labor wages. The solution to this is that both government and non-government can contribute by creating a program. This program is specifically aimed at reducing the costs incurred by farmers so that those who lack capital can still manage their farms in order to get high production yields and income. In general, farmers manage their farms individually, so that the production results from these farms are very diverse.

Agricultural conditions in Bantul Regency are characterized by narrow land areas in the form of small plots that are bordered by land boundaries. In addition, the youth's low interest in agriculture causes a lack of available manpower to help manage agricultural land. Meanwhile, most of the existing farmers are elderly. Based on the background of the existing conditions, the government initiated a program to overcome farmers' problems through a program called the corporate farming program.

The corporate farming (CF) program is one of the empowerment programs for farming communities with the aim of increasing farmer yields through effective management for more efficient results through better management. The CF program was successfully realized in desa Trimulyo, Bantul DIY and plays a very important role in the effort to empower farming communities so that the production results obtained are not unequal, or all farmers are prosperous. Joint management is expected to increase farm productivity. Production is considered to be efficient if the costs incurred are smaller than the results obtained or the production is greater than the costs incurred. With a planned program, the activities will become easier to carry out. The CF program carried out in desa Trimulyo had succeeded in convincing farmers to agree on commercial farming activities with one management, namely under farmer groups with technical guidance from academics and government.

Production can be increased by extensification, that is by expanding the land, and intensification, which is by optimizing land use such as utilizing technological innovations in the cultivation of agricultural crops. All of these efforts can be successful if they are supported by easier access to capital for farmers and provision of technical assistance from an institution. Without this, it will create a possibility for farmers to return to the old way again so that high productivity will be difficult to achieve (Firmana et al., 2017).

Production activities are said to be efficient if the use of input factors is less than the output produced. The CF program held in Bantul Regency is one of the programs with the aim of increasing efficiency through farming management with a "farming collectively" approach in the entire process with the application of technology. The corporate farming program is implemented with the aim of overcoming various problems, including the limitations of farmers' access to capital, availability of land and scarcity of labor. Through the CF program, farmers are introduced to various modern agricultural tools so that it is hoped that the problem of 
limited land as well as in the use of labor can be resolved. In addition, the CF program that is executed collectively makes it easier for farmers to manage their agricultural land. The amount of labor and time devoted by farmers is decreasing due to the use of modern agricultural machinery so that it is more efficient.

The concept of CF is essentially a collaboration with a management system from a small-scale business to a larger-scale business so that it fulfills economies of scale which can make the business more efficient, have high productivity, homogeneous products, and higher quality of production, which is a prerequisite to increase competitiveness. The CF program is also one way to effectively and efficiently increase farm productivity (Iskandar \& Jamhari, 2020; Ismiasih, 2020). Several studies on labor productivity and efficiency have been conducted by previous researchers, including Mamondol (2018) and Asrizal (2018).

The existence of a program will certainly have a significant impact and contribution for the actors. By holding the CF program in desa Trimulyo, it is hoped that farmers will gain an impact in their farming and productivity. Problems regarding resource scarcity and farm management can be solved by implementing the CF program. Based on the existing problems, the purpose of this research is to find out the implementation of the CF program activities in desa Trimulyo and the impact of the CF program on labor efficiency at the farmer level in rice farming in desa Trimulyo.

\section{METHOD}

The research was conducted by employing a descriptive method, which is a method that has a purpose in describing an object, the character of a variable, group, or social phenomenon that exists in society (Martono, 2014). The research location was chosen by using purposive sampling, which is in desa Trimulyo, with the consideration that in desa Trimulyo the CF program is being implemented. The research sample was determined by purposive sampling, which is by selecting farmers who really knew or had competence about the research topic (Martono, 2014). The sample consists of 30 farmers from a total population of 140 farmers as participants of the CF program. The determination of the sample with a total of 30 is based on the assumption that the sample is close to a normal distribution and is feasible in representing the population (Sugiyono, 2016). Data were collected through observation, interviews, and questionnaires, which is by giving structured questions to respondents. The types and sources of data were primary and secondary, which were obtained from the farmers, desa Trimulyo Officials, and the head of the farmer group, who knew in depth about the implementation of the CF Program.

The implementation of the CF program in desa Trimulyo was analyzed using a qualitative descriptive method. Rice productivity can be known by applying the following formula (Suratiyah, 2015):

Productivity= output dalam in one growing season (Kg/MT)

Harvested area $(\mathrm{Ha})$

description: $\mathrm{MT}=$ musin tanam (growing season)

The impact of the CF program on labor efficiency is analyzed using a paired sample t-test or a related sample t-test, which is an analysis of the same sample subject to an action whether the two have significantly different averages (Sugiyono, 2016).

The t-test formula (t-test) is calculated using the following model

$\mathrm{t}^{\prime}=\frac{\bar{X}_{1}-\bar{X}_{2}}{\sqrt{\left(S_{1}^{2} / n_{1}\right)+\left(S_{2}^{2} / n_{2}\right)}}$

Description:

$\bar{X}_{1}=$ average farm labor efficiency before the CF program

$\bar{X}_{2}=$ average farm labor efficiency after the CF program

$S_{1}=$ standard deviation of labor efficiency before the CF program

$\mathrm{S}_{2}=$ standard deviation of labor efficiency after the CF program

$\mathrm{n}_{1,2}=$ number of farmer samples

Hypothesis testing was carried out at the $95 \%$ confidence level or $a=0.05$. The proposed hypotheses are: 
$\mathrm{H}_{0}$ : It is suspected that there is no difference in labor efficiency before and after the implementation of corporate farming program.

$\mathrm{H}_{1}$ : It is suspected that there is a difference in labor efficiency before and after the implementation of corporate farming program

The test criteria are as follows:

a) If $t$ count $>t$ table, then $\mathrm{H}_{0}$ is rejected and $\mathrm{H}_{1}$ is accepted, meaning that there is a difference in labor efficiency before and after the CF program.

b) If $t$ count $\leq t$ table, then $\mathrm{H}_{0}$ is accepted and $\mathrm{H}_{1}$ is rejected, meaning that there is no difference in labor efficiency before and after the CF program.

\section{RESULTS AND DISCUSSION}

\section{Characteristics of Farmers in Desa Trimulyo}

Farmers as the CF program actors in desa Trimulyo were generally of productive age. Based on the identification of respondents, it can be seen that the age of farmers was in the age range of 58-64 years, with a total of 10 farmers $(33 \%)$. The youngest ages of farmers were in the age range of 44-50 years old, which included 3 farmers (10\%) and the oldest was in the age range of $72-78$ years with 3 farmers (10\%). Age is an important factor for farmers in farming because the older the farmer, the less efficient he is in managing his farm. The education background of farmers was mostly from the elementary school (SD) level with a total of 13 people (43.3\%). The highest level of education was in higher education (PT/university) with a total of 2 people $(6.7 \%)$, and the lowest was no - school with a total of 4 people $(13 \%)$. It implies that the average education of farmers was generally still low, which was the elementary school level. Thus, significantly influenced them in managing their farming. Education is one of the important factors in running a farming business because educated farmers will find it easier to accept new innovations such as the Corporate Farming program.

The average farming experience was in the range of 20-26 years with a total of 7 farmers $(23 \%)$ and the longest was in the range of $47-53$ years with a total of 2 farmers $(7 \%)$. While the least was in the range of $6-12$ years with a total of 5 people (17\%). Farming experience is one of the important factors that support the farmers' success in managing their farms. Hence, even though the average education of farmers is low, they were able to manage their farms because they were armed with experience. For farmers, farming experience is a learning process in running a farm. However, farming experience cannot reflect whether or not the farmers were implementing technological innovations easily because farmers in general were already accustomed to the old pattern as seen when farmers received the CF program where there were some members who were not motivated to join the program. Thus, some of their farms were handed over to be carried out by other team members

The average land ownership status of farmers was in their own ownership, with 16 farmers $(53.3 \%)$ and there were 14 farmers as sharecroppers (46.7\%). These sharecroppers were divided into 2 types. First, there were some sharecroppers whose production was divided by two with the owner $(1: 1)$ and there were also sharecroppers whose production was divided into 2 for the cultivator and 1 for the land owner (2:1). Afrianika, Marwanti \& Khomah, (2020) stated that land owned by sharecroppers/smallholders is more efficient in spending production costs compared to tenant farmers, due to the costs incurred by tenants in renting the land they manage. Therefore, if the management of the farm is handed over to the sharecroppers or the owner farmers, the productivity will be even better in the hope of getting more profit from the results of their production.

Farmer's land area is one of the input factors that also affects production results and production costs incurred by farmers. Based on the results, the average farmers' land ownership was 0-500 m2 with 13 farmers $(43.3 \%)$ and the largest area was $>2000 \mathrm{~m} 2$ with only 1 farmer $(3.3 \%)$. It can be seen that the average land ownership of farmers was relatively narrow ( $<500$ meters2) so that farmers' production results were low. Small land area can lead to the farming management system that cannot be optimal. The application of modern agricultural technology will be difficult to do. Land area is one of the determinants of production results because the larger the land area, the more production results obtained. Hence, with the implementation of the 
CF program, it is hoped that management will become easier so that farmers' production results are even better because the land is managed in a consolidated manner into a large expanse without any boundaries between farmers' lands, so that cultivation with the application of modern technology will be easy to carry out.

Table 1. Characteristics of Farmers in the Corporate Farming Program in desa Trimulyo, Jetis, Bantul, DIY

\begin{tabular}{|c|c|c|c|}
\hline No & Farmers' Characteristics & total (persons) & Percentage (\%) \\
\hline \multirow[t]{6}{*}{1} & Age (year old): & & \\
\hline & $44-50$ & 3 & 10,0 \\
\hline & $51-57$ & 7 & 23,3 \\
\hline & $58-64$ & 10 & 33,3 \\
\hline & $65-71$ & 7 & 23,3 \\
\hline & $72-78$ & 3 & 10,0 \\
\hline \multirow[t]{6}{*}{2} & Education level: & & \\
\hline & Elementary school & 13 & 43,3 \\
\hline & Junior high school & 5 & 16,7 \\
\hline & Senior high school & 6 & 20,0 \\
\hline & Higher education/university & 2 & 6,7 \\
\hline & No school & 4 & 13,3 \\
\hline \multirow[t]{8}{*}{3} & Farming Experience (year): & & \\
\hline & $6-12$ & 5 & 16,7 \\
\hline & $13-19$ & 6 & 20,0 \\
\hline & $20-26$ & 7 & 23,3 \\
\hline & $27-33$ & 3 & 10,0 \\
\hline & $34-40$ & 6 & 20,0 \\
\hline & $41-46$ & 1 & 3,3 \\
\hline & $47-53$ & 2 & 6,7 \\
\hline \multirow[t]{3}{*}{4} & Land ownership: & & \\
\hline & One's own & 16 & 53,3 \\
\hline & Sharecropper & 14 & 46,7 \\
\hline \multirow[t]{7}{*}{5} & Land area $\left(\mathrm{m}^{2}\right)$ : & & \\
\hline & $0-500$ & 13 & 43,3 \\
\hline & $501-1000$ & 8 & 26,7 \\
\hline & $1001-1500$ & 5 & 16,7 \\
\hline & $1501-2000$ & 3 & 10,0 \\
\hline & $2001-2500$ & 0 & 0,0 \\
\hline & $2501-3000$ & 1 & 3,3 \\
\hline
\end{tabular}

Source: Primary Data Analysis (Processed), 2020

\section{The Implementation of Corporate Farming Program}

Prior to the CF program, farmers in desa Trimulyo were doing their farming individually or independently. Farmers' land area was in the form of small plots because the land owned by farmers was small and narrow on average. There were borders between land owned by one farmer and another. Land preparation was done using a hoe or small tractor. Seeding was done by using more labor according to the size of the land. Planting also required more labor because the planting was done manually with human labor. The larger the area of the land owned by farmers; the more labor used by farmers would also be.

The CF program activities in desa Trimulyo have been held since 2017. Farmers involved in the CF program must be registered as members of the farmer group. This is done so in order to facilitate the delivery of information, coordination and responsibility for the implementation of the corporate farming program. The land for the implementation of the program was 6 ha which was owned by 140 farmers divided into 22 teams. The land owned by the farmers was combined with approximately 4-5 people in one (1) team and each team already had its own team leader. The farmer group that was chosen to conduct a trial of the corporate farming program was the Barokah Farmer group. The implementation of the corporate farming program began with socialization. After the farmers agreed, the new program could be proceeded. After that, the land preparation 
stage was begun by consolidating land or merging land owned by farmers so that there would be no longer borders between land owned and the land became one large area.

This is in line with the research by Dalimunthe \& Kurnia (2018), which states that corporate agriculture is an activity done by uniting agricultural land into one vast area with joint management by farmers and integrated into one single management. Land preparation is managed jointly by using large tractors and small tractors. Seedling and planting are done in groups using a seedling tool (dapog) and a planting machine (transplanter). The planting machine used by the Barokah Farmers group is a 2:1 jarwo planting machine, meaning 2 rows are close together and 1 row is far apart. The system of planting care, weeding, spraying insecticides to harvesting was done by the farmers themselves. The availability of insecticides wass managed by the group. Thus, the spraying process is carried out simultaneously by farmers. At the beginning of the implementation, meetings and counseling were often held, especially in learning about CF farming techniques and training to operate modern tools or machines and control pests and diseases.

The following are the stages of implementing corporate farming activities carried out by farmers in desa Trimuyo:

a. Land Preparation

Land preparation is the first step in starting a farm. One of the things that needs to be done by farmers in this activity is to cultivate the land so that it is ready to grow plants. Land preparation is done by using a tractor. In the Barokah farmer group, 2 types of tractors were used to plow the fields, which were a large tractor and a small tractor. Large tractors were used to plow fields that was of more than $1000 \mathrm{~m} 2$. Before the corporate farming program was carried out, some of the farmers were still doing land preparation manually using a hoe

b. Seedling

Seedling is the process of spreading seeds on land that has been prepared for a certain time so that they grow into seeds that are ready to be moved and planted on farm land.

Before the corporate farming program was held, seedling was done manually and individually. After the corporate farming program was implemented, the seedling process was done using a seedling machine (dapog) and managed in group.

c. Planting

Planting is the activity of planting seeds on a farming land. Prior to the CF program, planting activities were carried out manually by employing human labor. Meanwhile, after the corporate farming program was held, planting was done using a transplanting machine (transplanter).

d. Weeding

Weeding is an activity to clean unwanted wild plants or weeds in paddy fields. Before the program and after the CF program, weeding was done using the same method, which was manually by farmers using a hoe or gasrok. The duration for weeding the land depended on the volume of weeds in the farmers' land. For farmers who had large enough land, to control weeds sometimes involved other waged workers if farmers did not employ other workers' labor, usually the farmers controlled it themselves gradually day by day.

e. Watering

Irrigation is an activity to irrigate dry rice fields. Irrigation in the Barokah farmer group already utilized an irrigation system, so when the farmers' rice fields were dry, farmers could irrigate their fields by opening the cover of the water channel that flowed into the farmers' fields. The duration of the irrigation process depended on the dryness level of the land and the number of farmers who were irrigating the fields. If the farmer's land were completely dry, irrigation could take up to 3-4 hours. Similarly, if many farmers were doing irrigation at the same time, the irrigation time would take long too because the water flowing to the farmers' land had to be shared. Before and after the corporate farming program, the irrigation process was carried out individually. However, there were still several teams that were still compact as a CF team. These team divided the irrigation workforce of 2-3 HOK/4-5 farmers' land which had been combined into 1 team. 


\section{f. Fertilization and Pest Control}

Fertilization means giving nutrients to rice plants. Usually, farmers use NPK fertilizer. Before and after the corporate farming program, the fertilization process was done the same, that was individually. The application of NPK fertilizer was by sowing. Meanwhile, pest control is the eradication of pests in plants. Pest control was carried out by using organic insecticides, namely bacillus, which was made by the farmer groups themselves.

Prior to the CF program, insecticides were sprayed separately or not simultaneously. Meanwhile, after the CF program, the insecticide spraying process was carried out simultaneously with the insecticides that were already provided by the group. The duration of completing the application of fertilizers and insecticides usually lasted 2-3 hours.

g. Harvesting

Harvesting is the activity of harvesting the results of plant cultivation. Before and after the corporate farming program, harvesting was done in the same way, that was by using labor. The labor cost was usually 1 sack of grain divided by the number of workers. There were also those who were not paid because they were given forage instead that they used to feed their livestocks.

Table 2 presents the stages of the CF Program activities with agricultural machine tools (usually called alsintan in Bahasa Indonesia) used by farmers before and after the program. In terms of using machine tools, before the CF program, there were still many who used the tool manually. Meanwhile, after the program, the use of machine tools adopted the use of modern agricultural machinery

Table 2. Agricultural Machine Tools used Before and After The Corporate Farming Program

\begin{tabular}{clll}
\hline \multirow{2}{*}{ No. } & \multicolumn{1}{c}{ Activity } & \multicolumn{2}{c}{ Agricultural Machine Tools } \\
\cline { 3 - 4 } & & \multicolumn{1}{c}{ Before CF } & \multicolumn{1}{c}{ After CF } \\
\hline 1 & Land Prepartion & Hoe, Small Tractor & Large Tractor, Small Tractor \\
2 & Seedling & Manual & Seedling Machine (dapog) \\
3 & Planting & Ganual & Planting Machine (transplanter) \\
4 & Weeding & Irrigation & Gasrok (a weeder tool) \\
5 & Watering & Manual, Sprayer & Irrigation \\
6 & Fertilization and Pest Control & Manual, Sprayer \\
7 & Harvesting & Sickle & Sickle \\
\hline
\end{tabular}

Source: Primary Data Analysis (Processed), 2020

\section{Impact of Corporate Farming Program on Workforce Efficiency}

Labor is an input factor that plays an important role in supporting the achievement of production results. Manpower is a person who manages, runs or carries out the technical activities of a business. It is stated that manpower is a population of working age (10-64 years) who has the potential to do work and is able to produce goods or services. By regulating labor need properly, it is expected that the production of a business will be efficient. Efficient production can be obtained through a decrease in the cost of the labor involved, so that it can lead to an increase in income from its business commodities (Ulfah, Restuhadi \& Rosnita, 2016).

The average use of farmers' labor during farming activities before and after the Corporate Farming (CF) program can be seen in Table 3. The calculation of labor in farming is carried out using the Working Person Day (HOK/Hari Orang Kerja) unit. People's One Working Day (HOK) is approached by working for approximately seven hours. Based on the need for labor involved in farming (Table 3), it can be seen that the overall average labor need after the CF program was $716 \mathrm{HOK} / \mathrm{Ha}$ or $31.52 \mathrm{HOK} / \mathrm{UT}$. This means that after the program, the need for manpower was less than the average use of manpower before the CF program, which was $1464.76 \mathrm{HOK} / \mathrm{Ha}$ or $43.8 \mathrm{HOK} / \mathrm{UT}$. It can be seen that there is a difference in labor need in land preparation between before and after the CF program. Prior to the program, the workforce needed was 2.5 HOK/UT or $32.4 \mathrm{HOK} / \mathrm{Ha}$, while after the program the required manpower was $3.78 \mathrm{HOK} / \mathrm{UT}$ or $1.8 \mathrm{HOK} / \mathrm{Ha}$. The need for labor seems to have decreased because in the land preparation step, farmers had used agricultural machines, namely from small tractors to large tractors, so that their workforce needs became more efficient.

There was also a decrease in the need for labor in seedling activities. Before the program, the workforce needed was $24.73 \mathrm{HOK} / \mathrm{UT}$ or $843.18 \mathrm{HOK} / \mathrm{Ha}$ and after the program it was $14.97 \mathrm{HOK} / \mathrm{UT}$ or 498.89 $\mathrm{HOK} / \mathrm{Ha}$. The previous seedling activities were carried out manually, and after the program, seedling was 116 
carried out using agricultural tools called dapog, so that no large amount of labor was needed. The need for labor in planting also seems to have decreased significantly. Previously, the labor required was $6.73 \mathrm{Hok} / \mathrm{UT}$ or $381.93 \mathrm{HOK} / \mathrm{Ha}$, and after the program, planting required $2.46 \mathrm{HOK} / \mathrm{UT}$ or $1.12 \mathrm{HOK} / \mathrm{Ha}$. In the $\mathrm{CF}$ program, the rice planting process uses a transplanter machine so it does not require a lot of labor. Thus, the implementation of an effective CF program has reduced the number of labor due to the use of modern agricultural tools or machinery.

The application of modern agricultural machinery is easier to operate if the land is wider than if the land is still in the form of plots. Hence, with the CF program, farmers can be more effective in overcoming the shortage of labor in farming. This condition is due to the fact that after the CF program, many of their workforce were replaced by modern agricultural machinery, from land preparation to planting.

Table 3. The Average Need fo Labor in Farming With and Without the Implementation of CF Program in Desa

\begin{tabular}{|c|c|c|c|c|c|}
\hline \multirow{3}{*}{ No. } & \multirow{3}{*}{ Description } & \multicolumn{3}{|c|}{ Trimulyo } & \\
\hline & & \multicolumn{2}{|c|}{$\begin{array}{l}\text { The Need for Labor Before the CF } \\
\text { Program (HOK) }\end{array}$} & \multicolumn{2}{|c|}{$\begin{array}{c}\text { The Need for Labor After the } \\
\text { CF Program (HOK) }\end{array}$} \\
\hline & & Per UT & Per Ha & Per UT & Per Ha \\
\hline 1 & Land Preparation & 2,5 & 32,4 & 3,78 & 1,08 \\
\hline 2 & Seedling & 24,73 & 843,18 & 14,97 & 498,89 \\
\hline 3 & Planting & 6,73 & 381,93 & 2,46 & 1,12 \\
\hline 4 & Weeding & 4,8 & 57,2 & 5,07 & 62,07 \\
\hline 5 & Watering & 0,41 & 4,6 & 0,44 & 5,06 \\
\hline 6 & $\begin{array}{l}\text { Fertilization and Pest } \\
\text { Control }\end{array}$ & 0,48 & 5,85 & 0,58 & 6,73 \\
\hline 7 & Harvesting & 4,15 & 139,6 & 4,22 & 141,84 \\
\hline & Total & 43,8 & 1464,76 & 31,52 & 716,79 \\
\hline
\end{tabular}

Source: Primary Data Analysis (processed), 2020

Each program can certainly have a positive or negative impact, depending on how the farmers respond to it. Similar to the CF program, if farmers think positively about the program, the program can run smoothly even though their production yields declined. Ismiasih in her study (2020) concluded that the farmers' perception or response to the CF program in desa Trimulyo was quite positive. On average, farmers felt that with the CF program, farming in wetlands became easier and more efficient. As seen in Table 4, farmers' production during one harvest season showed a decrease in yields when compared to before the CF program. Farmer productivity before the CF program was higher than after, which was $323.03 \mathrm{Kg} / \mathrm{UT}$ or $3654.05 \mathrm{Kg} / \mathrm{Ha}$. After the CF program, the resulting productivity was $268 \mathrm{Kg} / \mathrm{UT}$ or $3023.73 \mathrm{Kg} / \mathrm{Ha}$. This is because when the research was being conducted for one season, farmers' rice paddy field was attacked by rats and insects so that their production decreased. Another contributing factor was the social aspect of farmers, where some farmers were not yet adaptive to the CF program so that farmers, in carrying out the program, are still not optimal.

Table 4. Average Productivity, Need for Labor (HOK) and Workforce Efficiency before and after the Corporate Farming Program

\begin{tabular}{clcccc}
\hline & \multirow{2}{*}{ Description } & \multicolumn{2}{c}{$\begin{array}{c}\text { Rice Farming before the CF } \\
\text { Program }\end{array}$} & \multicolumn{2}{c}{$\begin{array}{c}\text { Rice Farming after the CF } \\
\text { Program }\end{array}$} \\
\cline { 3 - 6 } & & Per UT & Per Ha & Per UT & Per Ha \\
\cline { 3 - 6 } 1 & Productivity (Kg) & 323,03 & 3654,05 & 268,13 & 3032,73 \\
2 & Need for Labor (HOK) & 43,8 & 1464,76 & 31,52 & 716,79 \\
3 & Workforce Efficiency (Kg/HOK) & 7,38 & 3,36 & 8,51 & 5,50 \\
& t-Test & & & & \\
& t- count & 1,18 & & & \\
& t-table & 1,67 & & & \\
\hline
\end{tabular}


Source: Primary Data Analysis (processed), 2020

Every farming activity wants to obtain optimal production results from a combination of various available input factors. According to Suratiyah (2015), farming is defined as the knowledge possessed by a farmer in allocating the availability of existing resources, such as land, human resources, capital, and equipment, effectively and efficiently to obtain high profits at a certain time. The availability of human resources is very influential on the resulting production. Their abilities and expertise can be used to manage the land by using the available equipment optimally so that the results obtained can be maximized. According to Suratiyah (2015), the measurement of labor efficiency can be done by comparing the number of jobs that can be completed per day per required workforce. The less the number of available workers with more production, the more efficient the work will be. Based on Table 4, it can be seen that the efficiency of labor before the CF program was $7.38 \mathrm{Kg} / \mathrm{UT}$ or $3.36 \mathrm{~kg} / \mathrm{Ha}$, while the efficiency of labor after the CF program was $8.51 \mathrm{~kg} / \mathrm{UT}$ or $5.50 \mathrm{~kg} / \mathrm{Ha}$. According to the results of the statistical test (t-test) the results of the t-count were 1.18 at $a=5 \%$ $(0.05)$ and the t-table was 1.67. This explains that t-count was smaller than t-table or in other words $\mathrm{Ho}$ is accepted and $\mathrm{Ha}$ is rejected, meaning that there is no difference in labor efficiency both before and after the CF program. The labor efficiency before the CF program was not much different from the labor efficiency after the CF program, or in other words, the labor efficiency of the two farms was the same.

\section{CONCLUSION}

1. The implementation of the corporate farming program in desa Trimulyo was carried out well, starting from the socialization stage to the implementation of the program, namely from land preparation, seedling, planting, irrigation, maintenance to harvesting. Activities from land preparation to planting were carried out in groups, while from weeding to harvesting were carried out by the land owners themselves. The use of modern tools and machinery was involved during land preparation, which was by using small tractors and large tractors. Seedling was done using a seedling machine (dapog). Planting was done using a transplanting machine (transplanter).

2. The impact of the corporate farming program on labor efficiency shows insignificant results. This means that the efficiency of the workforce both before and after the CF program is not much different or just the same. The need for the use of labor after the program was fewer than before the program because after the program, farmers utilized modern agricultural tools and machines in managing some of their farming.

\section{REFERENCES}

Afrianika, V. I., Marwanti, S., \& Khomah, I. (2020). Analisis Faktor-Faktor yang Mempengaruhi Produksi Usahatani Bawang Merah di Kecamatan Tawangmangu. Agriecobis: Journal of Agricultural Socioeconomics and Business, 3(2), 79. https://doi.org/10.22219/agriecobis.vol3.no2.79-86

Asrizal. (2018). Efisiensi Produksi dan Produktivitas Tenaga Kerja Industri Mikro dan Kecil di Indonesia. Menara Ekonomi, IV(2), 6-11. file:///C:/Users/hp/Downloads/682-1382-1-SM.pdf

Bawono. (2018). Peningkatan Efisiensi Usaha Tani Melalui Model Konsolidasi Corporate Farming. Jurnal Perencanaan DIY.

BPS. (2021). Jumlah Petani Hanya Tersisa 33,4 Juta Orang, Julukan Indonesia Negara Agraris Bisa Hilang.

Dalimunthe, I. M., \& Kurnia, G. (2018). Prospek Penerapan Sistem Corporate Farming (Studi Kasus di Koperasi Pertanian Gerbang Emas). Jurnal AGRISEP, 17(1), 11-22. https://doi.org/10.31186/jagrisep.17.1.11-22

Firmana, F., Nurmalina, R., \& Rifin, A. (2017). EFISIENSI TEKNIS USAHATANI PADI DI KABUPATEN KARAWANG DENGAN PENDEKATAN DATA ENVELOPMENT ANALYSIS (DEA). Forum Agribisnis, 6(2), 213-226. https://doi.org/10.29244/fagb.6.2.213-226

Iskandar, M. J., \& Jamhari, J. (2020). Efficiency of Rice Farming in the Corporate Farming Model in Central Java. AGRARIS: Journal of Agribusiness and Rural Development Research, 6(2). https://doi.org/10.18196/agr.6297

Ismiasih, I. (2020). Persepsi Petani Terhadap Program Corporate Farming Dalam Upaya Peningkatan Produktivitas Padi Di Desa Trimulyo Kabupaten Bantul DIY. file:///C:/Users/hp/Downloads/Prosidingseminar-Agroindustri-2020.pdf 
Mamondol, M. R. (2018). Efisiensi Penggunaan Faktor Produksi Tenaga Kerja dan Modal pada Usahatani Kedelai di Kelurahan Pamona Kecamatan Pamona Puselemba Kabupaten Poso. 2, 1-7. https://doi.org/10.31227/osf.io/gb3jk

Martono, N. (2014). Metode Penelitian Kuantitatif. PT RajaGrafindo Perkasa.

Ministry of Agriculture. (2021). Kementan: Petani Adalah Pelaku Utama Pembangunan Pertanian. https://www.pertanian.go.id/home/?show=news\&act=view\&id=2158

Sugiyono. (2016). Metode Penelitian Kuantitatif, Kualitatif, R\&D. ALFabeta.

Suratiyah, K. (2015). IImu Usaha Tani. Penebar Swadaya.

Ulfah, F., Restuhadi, F., \& Rosnita, R. (2016). Analisis Efisiensi Produksi Petani Padi Peserta Operasi Pangan Riau Makmur di Kabupaten Siak. SOROT, 11(1), 61. doi: 10.31258/sorot.11.1.3875 